\title{
IL-28B - Predictor of Sustained Virological Response for IFN-based Regimens in Chronic Hepatitis C and Criteria for Optimizing DAAs Indication
}

\author{
IOAN SERGIU MICU ${ }^{1}$, MARILENA MUSAT ${ }^{1 *}$, YOUSEF AL HAMIDI ${ }^{2}$, ANDRADA DUMITRU ${ }^{1}$, ANCA ROGOVEANU ${ }^{1}$, \\ ROXANA EMANUELA POPOIAG ${ }^{1}$ \\ ${ }^{1}$ Gastroenterology Department, Emergency Hospital of Constanta, 145 Tomis Blvd., 900591, Constana, Romania \\ ${ }^{2} O$ vidius University, Faculty of Medicine, 124 Mamaia Blvd., 900527, Constanta, Romania
}

\begin{abstract}
Chronic viral infections affecting the liver represents a global burden for medical comunities. More than 170 million individuals are infected chronically with hepatitis C virus (HCV), this accounting about 2-3\% of the world's population. Despite numerous progresses aquired in viral pahogenesis and treatment, chronic hepatitis C management is influenced by a multitude of factors. Interleukin IL-28 beta subunit (IL28B) demonstrated to be involved in both sustained virological response (SVR) to treatment, but even with spontaneous viral clearance without any therapy. In the era of direct antiviral agents (DAAs) we aimed to find out what was the real influence of IL28B phenotypes over the response to Peg-IFN and Ribavirin treatment in patients with chronic hepatitis $C$, many of theses being non-responders or relapsers, and as consequence, to optimize the referal of patients to more expensive and efficient treatments. In a retrospectively manner, we analyzed the IL28B phenotype and its influence over the rapid viral response (RVR), early viral response (EVR) and sustained viral response (SVR), in 250 patients HCV treated patients. We made correlations between the treatment response rates and the IL28B polymorphism.TT phenotype was correlated negatively with all parameters studied, while CC phenotype was correlated with the best response rates. We concluded that IL28B phenotypes interfere with the EVR and SVR rates, IL28B phenotype being an independent prognostic factor for antiviral treatment response in our patient groups, and according to this characteristics, we created the premise to optimize the patients referal to expensive therapies as DAAs.
\end{abstract}

Keywords: hepatitis C virus, IL-28 beta subunit,viral treatment

Chronic viral infections affecting the liver represents a global burden for medical comunities [1-3]. More than 170 million individuals are infected chronically with HCV, this accounting about $2-3 \%$ of the world's population [4]. The introduction of interferons in hepatitis $\mathrm{C}$ infection treatment in 1991 resolved justa part of the problem, hepatitis $C$ being still a global concern $[5,6]$.The combination of pegylated interferons with a direct antiviral called ribavirin increased dramatically the response success rates, these reaching up to $50-60 \%$. Still, about half of all affected patients have relapse or fail to eliminate the virus despite this combination $[7,8]$.

Spontaneous clearance of HCV infection is affected by a lothost factors. Polymorphisms in the region of the gene interleukin -28 beta subunit (IL28B) are associated with HCV clearance. The gene product, interferon (IFN)- $\gamma 3$ seems to be implicated in the immune response to $\mathrm{HCV}$. $[9,10]$

Interleukin -28 beta subunit (IL-28B) gene demonstrated to be involved in both SVR rates to treatment but even with spontaneous viral clearance without any therapy [11].

There were numerous studies concerning the involvement of IL-28B in the SVR in HCV reported in literature, all having concordant results. In this way we were witness to a new era of chronic HCV treatment, the indication of treatment being influenced by the IL-28B phenotype $[12,13]$.

IL28B testing was available to individualize treatments in specific HCV patient subgroups.

Clinicians involved in HCV treatments have expertise in using several biomarkers and genetic predictors to select the RBV dosage, and also the treatment duration. The positive association with favorable HCV outcome of the good IL-28B allele and the easy use in various clinical settings with, decided the test applicability in clinical decision-making [14].

The first application of IL28B genotype testing was to identify patients who might need the most the addition of a protease inhibitor to IFN based regimen. The addition of a protease inhibitor to IFN based regimen in patients with a non-favorable IL28B allele CT/TT was a major change produced by the genetic studies mentioned above in the management of the chronic hepatitis $C$.

Other host factors such as age, race, co-morbidities, biochemical and immune competence have been reported to influence sustained viral response rates and evolution of disease to complications as liver cirrhosis or hepatocellular carcinoma $[15,16]$. Younger age and Asian ethnicity look to positively influence the response to IFN based therapy, while African ancestry, advanced fibrosis, associated severe liver steatosis, obesity, and diabetes are associated with poor response.[17] Some biochemical factors, like low ratio of serum $\gamma$-glutamyl transferase/alanine transaminase $(\gamma$-GT/ALT) or low $\gamma$-GT, high levels of macrophage inflammatory protein (MIP)-1b, apolipoprotein B-100 (apoB-100), interleukin (IL)-12 and IL-18 have been reported as positive predictors for positive response [18].

\section{Aim}

In the era of DAAs, we aimed to retrospectively find out what was the real influence of IL28B genotypes over the

\footnotetext{
*email: egmarilena@gmail.com, Phone: +40752130899
} 
response to treatment with Peg-IFN and Ribavirin in patients with chronic hepatitis $\mathrm{C}$, many of thses being nonresponders or relapsers in order to prioritize the indication of DAAs.

\section{Experimental part}

Material and method

The study developed during one year and a half, between January 2017 and March 2019. We studied 250 patients diagnosed and treated for chronic hepatitis $C$ in Gastroenterology Department of Emergency Hospital St. Apostle Andrew Constanta County in the last ten years.

All patients were treated according to the national guideline for treatment refered to chronic hepatitis $\mathrm{C}$. 6 or 12 months treatment was recommended, in concordance to the initial level of the viral load.

Patients were analyzed for viral load at: 0 weeks baseline, 4 weeks - rapid virologic response (RVR), 12 weeks - early virological response (EVR), 48 weeks end of treatment (EOT), and 72 weeks - sustained virologic response (SVR).

IL28B polymorphism was analyzed at least once during the treatment period.

We made correlations between the treatment response rates and the IL28B phenotype.

\section{Results and discussions}

The polymorphism of IL 28B split our patients into three groups: 57 patients - phenotype CC, 81 patients - phenotype CT, 112 patients - phenotype TT. (Table 1)

In our study, patients were divided according to antiviral treatments follows: 140 patients (56\%) with Peg-IFN alfa $2 a+$ RBV , 110 patients (44\%) with Peg-IFN alfa 2b+ RBV.

According to the level of viral load at baseline, our patients presented following results: 73 patients $(29.20 \%)$ with RNA- VHC $<600.000 \mathrm{cp} / \mathrm{ml}, 177$ patients $(70.80 \%)$ with RNA-VHC $>600.000 / \mathrm{ml}$

The distribution of patients, according to IL28B polymorphism and baseline viral load can be followed in Table 1.

We measured the viral load at week 4 to investigate the rapid viral response (RVR), and we made correlations between RVR and the IL28B phenotype.

RVR was obtained in 54 patients (54.38\%) with CC allele, 26 patients $(45.61 \%)$ with CT allele and 31 patients (40.17\%) with TT allele.

CC allele showed to positively influence the RVR response, no matter the viral load.

The IL28B phenotype proved to be an essential predictor for RVR rates in our study, no-mater the viral load.

The mean viral check-up was realized at 12 weeks, these measurements being called early viral response (EVR).

41 patients ( 71.92 ) with CC allele, 44 patients (54.32\%) with CT allele, and 30 patients (26.78\%) with TT allele had EVR.

CC allele shoved to be a useful prognostic factor for EVR ( $p=0.0322$, ss).

As the statistic analyze demonstrated that CC phenotype of IL28B was more frequent correlated with EVR when patients were heterozygous for the IL28B good allele and those homozygous for the bad allele $(p=0.0292, s s)$.

The measurement of viral load at 24 weeks was done only in patients who had a detectable viral load at 12 weeks, but with $2 \log$ decrease of viral load compared to onset value. From the total of patients with negative EVR, 6 patients $(28.07 \%)$ with CC allele, 13 patients $(16.04 \%)$ with
CT allele and 15 patients (13.39\%) with TT allele had a decrease of viral load more than 2 logs.

From the total of patients who had a $2 \log$ decrease of viral load at 12 weeks of treatment, 6 patients (37.5\%) with CC allele, 13 patients (35.13\%) with CT allele and 15 patients (18\%) with TT allele of IL28B had undetectable viremia at 24 weeks of treatment. Those were called slow responders (SR).

The CC phenotype of IL28B showed to be a positive prognostic factor for treatment response for slow responders (SR), no matter the viral load ( $p=0.0441, \mathrm{sS})$.

According to the SR status, our study results showed that 2 patients $(66.66 \%)$ with CC allele, 3 patients $(60 \%)$ with CT allele and 2 patients (50\%) with TT allele had viral load $<600.000 \mathrm{cp} / \mathrm{ml}$ at the treatment initiation.

CC allele was found as being a prognostic factor for SVR in patients with viral load $<600.000 \mathrm{cp} / \mathrm{ml}$.

The 24 weeks of treatment was considered the EOT for patients with low viral load at baseline and undetectable viral load at 4 weeks.

Our study result concludes that 16 patients $(88.88 \%)$ with CC allele, 17 patients (77.27\%) with CT allele and 18 patients (60\%) with TT allele had EOT undetectable at 24 weeks.

The 48 weeks evaluation revealed the following results:

For patients who ended the treatment at 24 weeks, the 48 weeks evaluation was considered the final assessment. We found that 12 patients $(66.66 \%)$ with CC allele, 8 patients (36.36\%) with CT allele and 7 patients (21.21\%) with TT allele had SVR.

CC allele of IL28B proved to be again a good prognostic factor for SVR in patients with viral load $<600.000 \mathrm{cp} / \mathrm{ml}$ $(p=0.007, s s)$.

From the total of patients, 29 patients (50.87\%) with CC allele, 32 patients ( $39.50 \%$ ) with CT allele, and 30 patients (28.78\%) of patients with TT allele had SVR.

The best response was obtain in CC alele patients $(p=0.0290, s s)$.

In patients with EVR and SVR, our study results showed that 16 patients $(28.07 \%)$ with CC allele, 14 patients (17.28\%) with CT allele and 15 patients (13.39\%) with TT allele had SVR.

CC allele of IL28B was more frequently involved in SVR response comparing with other alleles in patients with previous EVR.

From the total of SVR patients, 3 patients (50\%) with CC allele, 2 patients (40\%) with CT allele, and 1 patient $(25 \%)$ with TT allele had SVR. CC allele showed to be a positive factor who influence the SVR compared to TT allele $(p=0.0379, s s)$.

From the total of patients, the above patients represent $5.26 \%, 2.46 \%$, respectively $0.89 \%$.

The statistic analyzes revealed that genotypes CC and CT are good prognostic factors comparing with TT genotype. $(p=0.0027$, respectively $p=0.0031$, ss).

Optimizing the length of treatment for chronic hepatitis $C$ was a global concern during the IFN based regimen era. The lack of prognostic factors associated with SVR rates made physicians to actively involve in detection of such prognostic criteria and to use them prior to treatment decision with IFN based regimens or DAAs. [19] The discovery of IL-28B phenotypes and their involvement in treatment response in chronic hepatitis $\mathrm{C}$ made possible the individulization of treatment according to length. The prolongation of treatment to 72 weeks or the reduction to only 24 weeks was possible using this prognostic tools. Then, in easy to treat genotypes like 2 and 3 , the length of treatment was even more shortened to 12 or 16 weeks if 
Table 1

THE DISTRIBUTION OF PATIENTS ACCORDING IL28B PHENOTYPE AND RESPONSE RATES TO TREATMENT

\begin{tabular}{|l|l|l|l|}
\hline \multirow{2}{*}{\begin{tabular}{l} 
Clinical/ab parameters \\
\cline { 2 - 4 }
\end{tabular}} & \multicolumn{3}{|l|}{ IL28B phenotype } \\
\cline { 2 - 4 } $\begin{array}{c}\text { CC } \\
\quad 600.000 \mathrm{cp} / \mathrm{ml} \\
\quad 600.000 \mathrm{cp} / \mathrm{ml}\end{array}$ & 18 & 22 & 33 \\
\hline RNA-VHC & 39 & 59 & 79 \\
\hline RVR & 45 & 26 & 31 \\
\hline EVR & 41 & 44 & 30 \\
\hline SVR & 12 & 8 & 7 \\
\hline
\end{tabular}

RVR is achieved. The IL-28B genotype has been shown to affect RVR in two large trials of boceprevir/PEG-IFNa/RBV (RESPOND-2 / SPRINT-2) and made possible to shorten treatment using prognostic value of IL-28B genotype. [ $20-$ 22] In our study, RVR was influenced by the IL-28B genotype, the CC allele being more often correlated with good positive RVR. The research demonstrated that RVR is stronger in predicting SVR rates than IL-28B, and genotyping did not change clinical practice, making the genetic predictor sometimes unnecessary. Studies have also checked whether IL28B genotype can be used to intensify treatment dose or duration. [14] A higher dose of PEG-IFN produced higher response rates in patients with previous treatment failure heterozygous for the IL 28B allele vs. those homozygous for the harmful allele. For patients infected with HCV genotype 2 or 3 current standard of care is a 24week treatment course of IFN - based therapy and in cases with IL-28B non-favorable allele one can consider treatment extension from the usual 24 to 48 weeks. [23] In the same way, in genotype 1 and 4 infection treatment extension to 72 weeks in non- or slow-responders with IL28B CT/TT genotype might increase SVR substantially, this situation being resolved where available by the use of DAAs. $[14,24]$

\section{Conclusions}

In our study, the results revealed that IL28B phenotypes interfere with the EVR and SVR rates, IL-28B being an independent prognostic factor for antiviral treatment response in patients treated with IFN-based therapy. Harmfull CT and TT allele should offer priority for DDAS treatment for patients wearing these phenotypes of IL-28B.

\section{References}

1.LEBLEBICIOGLU, H., ARAMA ,V, CAUSSE, X., MARCELLIN, P., OZARAS, R., POSTAWA-KLOZINSKA, B., SIMON K, SUCEVEANU, A.I., WIESE, M., ZEUZEM, S. et al. J ournal of Viral Hepatitis,21, nr.9,2014, p.662-70.

2.GHEORGE, L., CSIKI, I.V., IACOB, S., GHEORGHE, C., TRIFAN, A., GRIGORESCU, M., MOTOC, A., SUCEVEANU, A.I., CURASCU, M., CARUNTU, F., et al, J Gastrointestin Liver Dis. 24,nr.4,2015,p. 413-421. 3.SUCEVEANU, A.I., MAZILU, L., VOINEA, C., SUCEVEANU, A.P., Hepatitis Monthly, 18,nr.5,2018, e60156.

4.ALTER, M.J. World J Gastroenterol.,13,nr.17, 2007,p. 2436-41.

5.GHANY, M.G., NELSON, D.R, STRADER, D.B., THOMAS, D.L., SEEFF, L.B. Hepatology 54,nr.4,2011,p. 1433-44.

6.PANTEA STOIAN, A.,SUCEVEANU, A.I.,BONTAS, E., et al. Conference: 35th Balkan Medical Week on Healthy Ageing - An Endless Challenge Location: Athens, Greece Date: SEP 25-27, 2018 Proceedings Of The 35th Balkan Medical Week,2018,p.117-121.

7.MCHUTCHISON, J.G., LAWITZ, E.J ., SHIFFMAN, M.L., et al., N Engl J Med. 361,nr.6,2009, p. 580-593.

8.GE, D., FELLAY, J., THOMPSON, A.J, et al., Nature, 461,nr.7262, 2009,p.399-401.

9.RAUCH, A., KUTALIK, Z., DESCOMBES, P., et al. Gastroenterology., 138,nr.4,2010, p.1338-1345.

10.SUPPIAH, V., MOLDOVAN, M., AHLENSTIEL, G., et al., Nat Genet., 41,nr.10,2009, p. 1100-104.

11.THOMAS, D.L., THIO, C.L., MARTIN, M.P., et al., Nature, 461.nr.7265,2009,p.798-801.

12.BALAGOPAL, A., THOMAS, D.L., THIO, C.L., Gastroenterology, 139,nr.6,2010, p. 1865-76.

13.DE CASTELLARNAU, M., APARICIO, E., PARERA, M., et al., PLOS One, 7,nr.2,2012,p.e31016.

14.HINDORFF, L., MACARTHUR, J., WISE, A., et al. A Catalog of Published Genome-Wide Association Studies.,2012.

15.SUCEVEANU, A.I., MAZILU, L., TOMESCU, D., CIUFU, N., PAREPA, I.R., SUCEVEAN, A.P, Chirurgia, 108,nr.5,2013, p.684-88.

16.POPOIAG, R.E., PANTEA-STOIAN, A.,SUCEVEANU, A.P., et al., J ournal Of Mind And Medical Sciences,6,nr.1,2019,p.26-30.

17.GHEORGHE, G.,PANTEA STOIAN, A., GAMAN, M.A. et al. Rev. De Chim.(Bucharest), 70, no. 2,2019,p.651-655.

18.SALGADO, M., KIRK, G.D., COX, A., et al. AIDS, 25,nr.3,2011 pp 385-387.

19.SUCEVEANU, A.I., STOIAN, A.P., MAZILU, L., VOINEA, F., HAINAROSIE, R., DIACONU, C.C., PITURU, S., NITIPIR, C., BADIU, D.C., CEAUSU, I., SUCEVEANU, A.P., Farmacia, 66, nr.5, 2018,p. 904908.

20. MCHUTCHISON, J.G., LAWITZ, E.J ., SHIFFMAN, M.L., et al. N Engl J Med., 361,2009, p. 580-93.

21..ERMAN, K., KWO, P.Y., Clin Liver., 13,2009, p.429-39.

22.MEDERACKE, I., WEDEMEYER, H., MANNS, M.P., Curr Opin Investig Drugs 10,2009, p. 181-9.

23.TANAKA, Y., NISHIDA, N., SUGIYAMA, M., et al., Nat Genet., 41, nr.10, 2009,p. 1105-1109.

24. GINGHINA, O.,BURCEA-DRAGOMIROIU, G.T.A.,GALATEANU, B., et al. Farmacia,67, nr.1,p.18-26.

$\overline{\text { Manuscript received: } 22.08 .2019}$ 